\title{
AGROGSTA
}

Journal Agroista. Vol. 5 ,No.2 November 2021

Journal home page: https://jurnal.instiperjogja.ac.id/index.php/AGI

ISSN : $2597-3835$

e-ISSN : : $2684-7019$

\section{PENGARUH PUPUK NPK DAN PUPUK SILIKA TERHADAP PERTUMBUHAN BIBIT KELAPA SAWIT (Elaeis guineensis Jacq.) DI PEMBIBITAN UTAMA}

\section{EFFECT OF NPK AND SILICA FERTILIZER ON THE GROWTH OF OIL PALM SEEDLING (Elaeis guineensis Jacq.) IN MAIN NURSERY}

\author{
Chronika Maria Vombora Sitorus $^{1}$, Titin Setyorini ${ }^{1}$, Sri Suryanti ${ }^{1}$ \\ ${ }^{1}$ Department of Agrotechnology, Faculty of Agriculture, Stiper Agricultural Institute, \\ Yogyakarta, Indonesia \\ Corresponding author: titin@instiperjogja.ac.id
}

\begin{abstract}
ABSTRAK
Pengaruh cekaman kekeringan akibat perubahan iklim memerlukan suatu upaya untuk menjaga ketahanan tanaman dengan cara pemberian pupuk silika (Si) yang dikombinasikan dengan pupuk NPK. Penelitian ini bertujuan untuk mengetahui pengaruh pupuk NPK dan pupuk silika terhadap pertumbuhan bibit kelapa sawit. Penelitian ini dilaksanakan pada bulan Desember 2019 sampai dengan Mei 2020, bertempat di desa Maguwoharjo, Kecamatan Depok, Kabupaten Sleman, Yogyakarta dan Laboratorium Sentral, Institut Pertanian Stiper, Yogyakarta. Penelitian ini merupakan percobaan faktorial yang disusun dalam Rancangan Acak Lengkap (Completely Randomized Design). Faktor pertama adalah pupuk NPK (16-1616) yang terdiri dari tiga aras yaitu, tanpa pupuk NPK, pupuk NPK (2,5 g/bibit), pupuk NPK (5 $\mathrm{g} /$ bibit). Faktor kedua adalah pupuk silika (SiO2) yang terdiri dari empat aras yaitu, tanpa pupuk silika, pupuk silika 5\% (10 ml/bibit), dan pupuk silika 10\% (20 ml/bibit), pupuk silika 15\% (30 ml/bibit). Setiap perlakuan dilakukan 5 kali ulangan sehingga jumlah bibit kelapa sawit keseluruhan adalah 60 bibit. Hasil penelitian dianalisis dengan menggunakan metode Analysis of Variance (Anova) pada jenjang nyata $5 \%$ dan untuk mengetahui beda nyata antar perlakuan diuji dengan uji Duncan's Multiple Range Test (DMRT) pada jenjang nyata 5\%. Hasil penelitian menunjukan tidak adanya interaksi nyata antara pupuk NPK dan pupuk silika terhadap pertumbuhan bibit kelapa sawit. Pemberian pupuk NPK dengan berbagai dosis dan pupuk silika dengan berbagai konsentrasi memberikan pengaruh yang sama terhadap seluruh parameter yang diamati, akan tetapi dosis 2,5 g/bibit dan konsentrasi $10 \%$ memberikan nilai rata-rata tertinggi hampir di semua parameter pengamatan.
\end{abstract}

Kata kunci: Bibit kelapa sawit, pembibitan utama, pupuk NPK, dan pupuk silika 


\section{PENDAHULUAN}

Kelapa Sawit (Elaeis guineensis Jacq.) ialah komoditas perkebunan yang unggul serta utama di Indonesia. Pada 5 tahun terakhir ini, informasi yang dirilis oleh Badan Pusat Statistik (2019) menunjukkan bahwa peningkatan terjadi pada luas lahan dan produksi tanaman kelapa sawit yang diusahakan oleh perkebunan-perkebunan baik milik negara maupun swasta yaitu pada tahun 2015 luas lahan sawit mencapai 11,26 juta ha dengan produksi sebesar 31,07 juta ton kemudian pada tahun 2019 mengalami peningkatan luas lahan menjadi 14,60 juta ha dengan produksi 48,42 juta ton.

Penggunaan pupuk yang tepat, ramah lingkungan serta cara dalam penyediaan bibit adalah salah satu upaya yang dapat dilakukan untuk meningkatkan produksi (Kartika, 2000 cit. Nurseha et al., 2014). Kemampuan tanaman dalam menghadapi kondisi cekaman kekeringan dilapangan merupakan salah satu kriteria bibit yang baik. Perlu diciptakan keadaan yang mendukung perkembangan bibit itu sendiri seperti, ketersediaan unsur hara makro dan mikro yang cukup (Lubis dan Widnarko, 2011 cit. Nengsih, 2015). Na, Si, Co, Cl, Al adalah unsur hara mineral yang bermanfaat pada beberapa jenis tanaman, tetapi tidak bersifat esensial (Pahan, 2012).

Selama masa pembibitan pemupukan ialah salah satu cara dalam meningkatkan produksi tanaman. Pemupukan dilakukan untuk memenuhi kebutuhan hara tanaman di dalam tanah yang jumlahnya terbatas, sehingga perlu diberikan unsur hara tambahan dari luar untuk nantinya dapat diserap oleh tanaman dengan baik guna mendukung proses perkembangannya. Pemberian pupuk anorganik lebih didominasi hal ini dikarenakan pupuk tersebut memiliki daya serap yang cepat sehingga meningkatkan produksi yang besar serta tingginya kandungan hara tetapi merugikan jika diaplikasikan secara berlebihan.

Pupuk NPK merupakan salah satu jenis pupuk anorganik yang paling umum digunakan dalam kegiatan budidaya tanaman salah satunya kegiatan pembibitan kelapa sawit baik itu di pembibitan awal (Pre-nursery), maupun di pembibitan utama (Main nursery). Nitrogen, Fosfor, dan Kalium adalah unsur hara yang terkandung di dalam pupuk NPK. Menurut Sastrosayono, (2007) cit. Nengsih, (2015) selama masa pembibitan utama (Main nursery) diperlukan pempukan yang cukup serta dosis yang sesuai dengan umur bibit, yang mana pada bibit umur 3-4 bulan dosis pupuk NPK (16-16-16) yang dibutuhkan $5 \mathrm{~g} / \mathrm{bibit}$ dan diberikan 2 minggu sekali. Menurut Sunarko, (2007) cit. Nengsih, (2015) sebanyak 20 g/tanaman setiap sebulan sekali ialah dosis pupuk NPK (16-16-16) di pembibitan utama.

Pengaruh cekaman kekeringan merupakan akibat dari pergantian iklim di lapangan, sehingga diperlukan suatu upaya untuk menjaga ketahanan tanaman dengan cara pemberian pupuk silika ( $\mathrm{Si}$ ) bagi tanaman dalam bentuk tersedia (SiO2). Kehilangan air pada masa kekeringan dapat diatasi dengan adanya lapisan silika gel di permukaan daun sehingga terjadi 
penghambatan laju transpirasi pada tanaman (Issukindaryah, 2013 cit. Dewi et al., 2014). Pada penelitian Dewi et al., (2014) menyatakan bahwa kisaran 5,1-10,2 gram/bibit merupakan dosis optimal untuk menginduksi ketahanan bibit kelapa sawit dari dampak kekeringan dengan cara pengerasan, pemanjangan dan perluasan akar serta stomata yang tetap membuka lebar.

\section{METODOLOGI}

Penelitian dilaksanakan di desa Maguwoharjo, Kecamatan Depok Kabupaten Sleman, Yogyakarta. Penelitian dilaksanakan pada bulan Desember 2019 sampai dengan Mei 2020. Penelitian ini merupakan percobaan faktorial yang disusun dalam Rancangan Acak Lengkap (RAL). Faktor pertama adalah pupuk NPK (16-16-16) yang terdiri atas tiga aras yaitu, tanpa pupuk NPK (kontrol), pupuk NPK 2,5 g/bibit, dan pupuk NPK 5 g/bibit. Faktor kedua adalah pupuk Silika yang terdiri dari empat aras yaitu, tanpa pupuk silika (kontrol), pupuk silika 5\%, pupuk silika $10 \%$, dan pupuk silika $15 \%$. Hasil penelitian dianalisis dengan menggunakan metode Analysis of Variance (Anova) pada jenjang nyata 5\%.Apabila hasil analisi sidik ragam beda nyata, maka dilanjutkan dengan uji jarak berganda Duncan (Duncan Multiple Range Test/DMRT) pada taraf $5 \%$.

Media tanam yang digunakan dalam penelitian adalah tanah regosol yang telah diayak kemudian tanah hasil ayakan dimasukkan ke dalam polibag yang berukuran $15 \mathrm{~cm} \times 22 \mathrm{~cm}$, diratakan dan dipadatkan. Pemupukan dilakukan dengan menggunakan pupuk anorganik NPK (16:16:16) dan dilakukan 4 minggu setelah tanam dengan pemberian pupuk NPK sesuai dosis yang telah ditentukan. Untuk pemupukan dilakukan 2 minggu sekali sehingga dalam satu bulan hanya dilakukan dua kali pemupukan. Pemupukan pertama dengan menggunakan pupuk NPK dosis yang digunakan sesuai perlakuan dan waktu aplikasi setiap minggu ganjil, pemupukan kedua dengan pupuk silika cair sesuai dengan perlakukan yang diaplikasikan setiap minggu ganjil

\section{HASIL DAN PEMBAHASAN}

Hasil penelitian ditunjukkan pada Tabel 1 dan Tabel 2. Hasil penelitian menunjukan bahwa pengaplikasian pupuk NPK dan pupuk silika menunjukkan tidak terjadi interaksi nyata terhadap seluruh parameter yang diamati. Dengan demikian, masing-masing faktor tidak saling bekerjasama dalam mempengaruhi pertumbuhan bibit kelapa sawit. 
Tabel 1. Pengaruh pemberian pupuk NPK secara tunggal terhadap pertumbuhan kelapa sawit.

\begin{tabular}{lrrr}
\hline \multicolumn{1}{c}{ Parametar Pengamatan } & \multicolumn{3}{c}{ Dosis Pupuk NPK } \\
& 0 & 2,5 & \multicolumn{1}{c}{5} \\
\hline Tinggi bibit (cm) & $30,85 \mathrm{p}$ & $32,27 \mathrm{p}$ & $32,27 \mathrm{p}$ \\
Jumlah daun (helai) & $6,05 \mathrm{p}$ & $6,15 \mathrm{p}$ & $6,25 \mathrm{p}$ \\
Diameter batang (mm) & $12,10 \mathrm{p}$ & $12,35 \mathrm{p}$ & $12,10 \mathrm{p}$ \\
Luas daun (cm) & $308,40 \mathrm{p}$ & $346,21 \mathrm{p}$ & $316,76 \mathrm{p}$ \\
Berat segar tajuk (g) & $19,23 \mathrm{p}$ & $21,01 \mathrm{p}$ & $19,70 \mathrm{p}$ \\
Berat kering tajuk (g) & $4,12 \mathrm{p}$ & $4,59 \mathrm{p}$ & $4,42 \mathrm{p}$ \\
Berat segar akar $(\mathrm{g})$ & $7,96 \mathrm{p}$ & $9,01 \mathrm{p}$ & $8,78 \mathrm{p}$ \\
Berat kering akar $(\mathrm{g})$ & $1,53 \mathrm{p}$ & $1,64 \mathrm{p}$ & $1,55 \mathrm{p}$ \\
Jumlah stomata (stomata/mm) & $34,25 \mathrm{p}$ & $31,65 \mathrm{p}$ & $35,75 \mathrm{p}$ \\
\hline
\end{tabular}

Keterangan : Angka rerata yang diikuti huruf yang sama pada tiap baris yang sama menunjukkan tidak ada beda nyata berdasarkan hasil uji DMRT pada jenjang nyata $5 \%$.

Tabel 1 menunjukan bahwa pemberian pupuk NPK dengan berbagai dosis secara tunggal tidak berpengaruh nyata pada sejumlah parameter. Hal ini diduga karena pupuk NPK yang diberikan belum mampu secara nyata mempengaruhi pertumbuhan tanaman. Pertumbuhan bibit kelapa sawit pada awalnya sangat dipengaruhi oleh ketersediaan cadangan makanan (endosperm) yang terdapat di biji. Nazari (2008) menyatakan bahwa meningkatnya pertumbuhan tanaman dapat disebabkan oleh ketersediaan cadangan makanan (endosperm) yang terdapat dalam biji pada dua bulan pertama penanaman dan penambahan pupuk NPK pada bulan ketiga mampu menyediakan unsur hara yang cukup bagi tanaman.

Pada perlakuan NPK dosis 2,5 g/bibit menunjukkan nilai rata-rata tertinggi pada parameter tinggi tanaman, luas daun, berat segar akar, dan berat kering akar, berat segar tajuk, berat kering tajuk. Hal ini diduga unsur hara yang terkandung di dalam pupuk dapat memacu perkembangan bibit dengan baik karena terjadinya proses akumulasi fotosintat yang dihasilkan oleh tanaman melalui proses fotosintesis yang ada kaitannya dengan kandungan dan peranan unsur N, P, dan K melalui pemberian pupuk NPK itu sendiri. Hal ini sejalan dengan pendapat dari Lingga dan Marsono, (2005) menyatakan bahwa pemberian unsur hara dengan dosis tertentu memberikan dampak yang baik tetapi pemberian dosis yang sedikit tidak akan memberikan dampak nyata pada tanaman sedangkan dosis yang berlebihan akan menyebabkan keracunan. 
Tabel 2. Pengaruh pemberian pupuk silika secara tunggal terhadap pertumbuhan kelapa sawit.

\begin{tabular}{lrrrr}
\hline \multicolumn{1}{c}{ Parametar Pengamatan } & \multicolumn{4}{c}{ Konsentrasi Pupuk Silika } \\
& \multicolumn{1}{c}{$5 \%$} & $10 \%$ & \multicolumn{1}{c}{$15 \%$} \\
\hline Tinggi bibit (cm) & $31,24 \mathrm{a}$ & $31,03 \mathrm{a}$ & $32,56 \mathrm{a}$ & $30,85 \mathrm{a}$ \\
Jumlah daun (helai) & $6,20 \mathrm{a}$ & $6,40 \mathrm{a}$ & $6,13 \mathrm{a}$ & $5,87 \mathrm{a}$ \\
Diameter batang $(\mathrm{mm})$ & $12,73 \mathrm{a}$ & $12,53 \mathrm{a}$ & $12,07 \mathrm{a}$ & $11,40 \mathrm{a}$ \\
Luas daun $\left(\mathrm{cm}^{2}\right)$ & $323,35 \mathrm{a}$ & $313,73 \mathrm{a}$ & $350,42 \mathrm{a}$ & $307,66 \mathrm{a}$ \\
Berat segar tajuk $(\mathrm{g})$ & $20,90 \mathrm{a}$ & $19,30 \mathrm{a}$ & $21,55 \mathrm{a}$ & $18,18 \mathrm{a}$ \\
Berat kering tajuk $(\mathrm{g})$ & $4,32 \mathrm{a}$ & $4,34 \mathrm{a}$ & $4,89 \mathrm{a}$ & $3,97 \mathrm{a}$ \\
Berat segar akar $(\mathrm{g})$ & $8,85 \mathrm{a}$ & $8,07 \mathrm{a}$ & $9,19 \mathrm{a}$ & $8,23 \mathrm{a}$ \\
Berat kering akar $(\mathrm{g})$ & $1,62 \mathrm{a}$ & $1,49 \mathrm{a}$ & $1,72 \mathrm{a}$ & $1,46 \mathrm{a}$ \\
Jumlah stomata & $39,67 \mathrm{a}$ & $33,73 \mathrm{a}$ & $28,13 \mathrm{a}$ & $34,00 \mathrm{a}$ \\
(stomata/mm) & & &
\end{tabular}

Keterangan : Angka rerata yang diikuti huruf yang sama pada tiap baris yang sama menunjukkan tidak ada beda nyata berdasarkan hasil uji DMRT pada jenjang nyata $5 \%$.

Tabel 2 menunjukkan bahwa pemberian pupuk silika dengan berbagai konsentrasi secara tunggal tidak berpengaruh nyata pada semua parameter. Hal ini mungkin dikarenakan kebutuhan silika pada media tanam yang digunakan sudah tercukupi. Daya serap yang dimiliki oleh setiap tanaman berbeda-beda sehingga menyebabkan silika yang terakumulasi pada tanaman tidak sama (Trisnawati et al., 2017). Berdasarkan pernyataan Dewi et al., (2014) pemberian pupuk silika akan berpengaruh pada cekaman kekeringan melalui proses pengerasan, pemanjangan dan perluasan akar.

Pada perlakuan silika $10 \%$ memberikan nilai rata-rata tertinggi pada parameter tinggi tanaman, luas daun, berat segar tajuk, berat kering tajuk, berat segar akar, dan berat kering akar. Hal ini berarti pemberian silika juga mendukung dalam pertumbuhan tanaman. Hal ini sejalan dengan pendapat dari Santi (2016) yang menyatakan peningkatan serapan unsur $P$ pada tanaman dikarenakan terjadinya kompetisi antara Si dengan Al dan Fe yang mengikat $P$. Unsur hara $P$ merupakan bagian dari senyawa yang mengatur pertumbahan pada tanaman

\section{KESIMPULAN}

1. Tidak terjadi interaksi nyata antara perlakuan pupuk NPK dan pupuk silika terhadap pertumbuhan bibit kelapa sawit.

2. Pemberian pupuk NPK tidak berpengaruh terhadap pertumbuhan bibit kelapa sawit, akan tetapi dosis 2,5 g/bibit memberikan nilai rata-rata tertinggi hampir di semua parameter pengamatan.

3. Pemberian pupuk silika tidak berpengaruh terhadap pertumbuhan bibit kelapa sawit, akan tetapi konsentrasi $10 \%$ memberikan nilai rata-rata tertinggi hampir di semua parameter pengamatan. 


\section{DAFTAR PUSTAKA}

Badan Pusat Statistik. 2019. Statistik Kelapa Sawit Indonesia 2019. Jakarta : Badan Pusat Statistik.

https://www.bps.go.id/publication/2020/11/30/36cba77a73179202def4ba14/statistik-kelapasawit-indonesia-2019.html. Diakses pada tanggal 10 Januari 2020, pukul 10.00 WIB.

Dewi, Amanda Yashinta, Eka Tarwaca Susila Putra \& Sri Trisnowati. 2014. Induksi Ketahanan Kekeringan Delapan Hibrida Kelapa Sawit (Elaeis guineensis Jacq.) dengan Silika. Jurnal Vegetalika 3(3) : 1- 13.

Lingga P. dan Marsono. 2005. Petunjuk Penggunaan Pupuk. Jakarta : Penebar Swadaya.

Nazari, Y.A. 2008. Respon Pertumbuhan Bibit Kelapa Sawit (Elaeis guineensis Jacq.) pada Pembibitan Awal terhadap Pupuk NPK Mutiara. Ziraa'ah Majalah IImiah Pertanian Vol.23 No.3 :170-184.

Nengsih, Y. 2015. Pemberian Pupuk Organik Dan Pupuk Anorganik Terhadap Pertumbuhan Bibit Kelapa Sawit (Elaeis guineensis jacq.) Di Pembibitan Utama. Jambi : Jurnal IImiah Universitas Batanghari 15(4) : 107-112.

Nurseha, Danner Sagala \& Antonius Dalle. 2014. Penggunaan Macam Pupuk Dan Bentuk Aplikasinya Terhadap Pertumbuhan Bibit Kelapa Sawit Di Pembibitan Utama. Fakultas Pertanian, Universitas Prof. Dr. Hazairin,SH Bengkulu : Jurnal Agroqua 12(1) : 1-7.

Pahan, lyung. 2012. Panduan Lengkap Kelapa Sawit, Manajemen Agribisnis Kelapa Sawit dari Hulu hingga Hilir. Jakarta : Penerbar Swadya.

Santi, Laksmita Prima. 2016. Pemanfaatan Bio-Silika untuk Meningkatkan Produktivitas dan Ketahanan Terhadap Cekaman Kekeringan pada Kelapa Sawit. Mataram.

Trisnawati Dina Wahyu, Nugroho Susetya Putra \& Benito Heru Purwanto. 2017. Pengaruh Nitrogen dan Silika terhadap Pertumbuhan dan Perkembangan Spodoptera litura (Lepidoptera: Noctuidae) pada Kedelai. Fakultas Pertanian, Universitas Muhammadiyah Yogyakarta. Yogyakarta :Jurnal Agrosains. 